\title{
SISTEM INFORMASI MANAJEMEN SANTRI DI PONDOK PESANTREN AL ISHLAH KOTA KEDIRI
}

\author{
Ahmad Bagus Setiawan ${ }^{1)}$, Juli Sulaksono ${ }^{2)}$ \\ 1), 2) Program Studi Teknik Informatika, Fakultas Teknik, Universitas Nusantara PGRI Kediri \\ Jl KH. Achmad Dahlan Gg.1 Mojoroto Kota kediri \\ Email:ahmadbagus@unpkediri.ac.id ${ }^{1)}$,jsulaksono@unpkediri.ac.id ${ }^{2}$
}

\begin{abstract}
Abstrak
Penerapan sistem di pondok pesantren dilatarbelakangi dari penerapan pengarsipan data yang masih menggunakan sistem petok untuk pendataan pembayaran bulanan dan untuk pendataan biodata santri masih menggunakan buku folio, meskipun dalam perkembangannya sudah diterapkan aplikasi excel, tetapi masih belum bisa mendata secara rinci data santri, pembayaran santri dan tahun masuk dan keluar. Maka sistem Informasi Manajemen Pondok pesantren ini dapat kiranya membantu pondok pesantren dalam penerapan Sistem Integrasi Santri baik santri Madrasah maupun santri Pondok, terdapat data yang pasti, dapat memberikan informasi yang akurat dan cepat dalam menganalisa informasi.
\end{abstract}

Kata kunci: Pondok pesantren, Sistem Informasi, Santri

\section{Abstract}

The system application at the boarding school is based data archiving that still uses the petok system to collect monthly payments and a folio book to collect students data. Even though the Excel application has been applied, but it still cannot record detailed student data, payments santri also entry and graduation year. The Islamic Boarding School Management Information system can help Islamic boarding schools in Integration System both Madrasah and Pondok Santri students, where can provide accurate and fast in analyzing information.

Keywords: Islamic boarding school, Information System, Santri

\section{PENDAHULUAN}

Indonesia merupakan pusat pendidikan agama Islam, dimana banyak berdiri pondok pesantren dan madrasah yang dipimpin oleh seorang kyai atau ulama, Pondok Pesantren merupakan wadah untuk menuntut Ilmu agama islam. Maka perlu ada pengembangan manajemen dalam pengelolaan agar tetap bisa mengikuti perkembangan zaman. Sistem Informasi Manajemen Pondok Pesantren perlu dikembangkan untuk dapat mendata semua sumber daya manusia, dari kepengurusan, santri, dana madrasah dan pondok. Maka disini diberikan sebuah gagasan untuk pembuatan sistem manajemen pondok pesantren berbasis web, untuk memudahkan kepengurusan pondok pesantren untuk mengelola data santri data keuangan dan kurikulum yang diterapkan di pondok pesantren, sistem ini nantinya akan disesuaikan sesuai dengan kebutuhan pondok pesantren dengan berbasis modul. Jadi nantinya dapat digunakan oleh beberapa Pondok Pesantren, meskipun berbeda sistem manajemennya.

Dalam Identifikasi Masalah yang terdapat di Pondok Pesantren seperti Adanya pendataan secara manual dalam perekapan data santri, keuangan, dan data kepengurusan. Dalam perumusan masalah, diantaranya bagaimana menerapkan sistem informasi manajemen pondok pesantren untuk perekapan data santri, keuangan, dan data kepengurusan. Tujuan Penelitian membuat Sistem Informasi manajemen Pondok Pesantren dapat digunakan di semua pondok pesantren. Sistem Informasi manajemen Pondok pesantren dapat membantu dalam perekapan data santri, keuangan dan kepengurusan, dengan tujuan Khusus membuat sistem perekapan data santri di Pondok Pesantren Al-ishlah Bandar Kidul Kota Kediri, membuat sistem perekapan keuangan di Pondok Pesantren Al-ishlah Bandar Kidul Kota Kediri, membuat sistem perekapan data pengurus di Pondok Pesantren Al-ishlah Bandar Kidul Kota Kediri. Dengan pembatasan masalah penelitian dilakukan di Pondok Pesantren Al-Ishlah Bandar Kidul Kota Kediri, sistem Menggunakan Aplikasi berbasis website dengan bahasa pemograman PHP, database management System Xampp 


\section{DASAR TEORI}

Pondok Pesantren merupakan tempat untuk membentuk serta mendidik generasi muda, tetapi kebanyakan permasalahan Pondok Pesantren kesulitan dalam memberikan contoh penggunaan dari ilmu yang dipelajari khususnya bidang Teknologi Informasi, apalagi pesantren terkenal dengan tradisi salafnya. Melihat kondisi yang demikian Sistem Informasi Manajemen Pondok Pesantren (SIMPONPES) berbasis komputer yang menggunakan metode pemanfaatan Teknologi yang telah ada di pesantren sebagai salah satu sarana belajar santri.

a. Sistem Informasi

Telah diketahui bahwa informasi adalah sebuah bahan penting bagi manajemen. Sistem informasi dalam sebuah organisasi dibatasi oleh data yang dapat diperoleh, biaya untuk pengadaan, pengolahan dan penyimpanan dan sebagainya. Sebuah sistem informasi berdasarkan komputer biasanya dapat mengurangi biaya sekaligus meningkatkan kemampuan dan prestasi sistem informasi [1]. [2] mendefinisikan sistem informasi merupakan kumpulan dari perangkat keras dan perangkat lunak komputer serta perangkat manusia yang akan mengolah data menggunakan perangkat keras dan perangkat lunak tersebut. Menurut [3] Sistem informasi adalah sistem didalam suatu organisasi, yang mempertemukan kebutuhan pengolahan transaksi harian, mendukung operasi bersifat manajerial dan kegiatan strategi dari suatu organisasi dan menyediakan pihak luar tertentu dengan laporan-laporan yang diperlukan. Sistem Informasi Manajemen atau SIM adalah suatu sistem berbasis komputer yang membuat informasi tersedia bagi para pengguuna yang memiliki kebutuhan serupa [4]. Dalam pendapat lain, [5] menjelaskan bahwa SIM ini adalah kumpulan sistem yang terkoordinasi dan bersifat rasional. Sistem tersebut bekerja untuk mengolah data menjadi sebuah informasi yang berharga.

Selain itu sistem informasi dapat didefinisikan sebagai berikut :

1. Suatu sistem yang dibuat oleh manusia yang terdiri komponen- komponen dalam organisasi untuk mencapai suatu tujuan yaitu menyajikan informasi.

2. Sekumpulan prosedur organisasi yang pada saat dilaksanakan akan memberikan informasi bagi pengambil keputusan dan atau untuk mengendalikan organisasi.

3. Suatu sistem didalam suatu organisasi yang mempertemukan kebutuhan pengolahan transaksi, mendukung operasi, bersifat manajerial dan kegiatan strategi dari suatu organisasi dan menyediakan pihak luar tertentu dengan laporan-laporan yang diperlukan.

Sistem informasi dapat terdiri dari komponen-komponen yang disebut dengan istilah blok bangunan (building block), yaitu blok masukan (input block), blok model (model block), blok keluaran (output block), blok teknologi (technology block), blok dasar data (database block) dan blok kendali (control block). Sebagai suatu sistem, keenam blok tersebut masing-masing saling berinteraksi satu dengan yang lainnya membentuk satu kesatuan untuk mencapai sasarannya.

Blok masukan : merupakan input yang mewakili data yang masuk kedalam sistem informasi yang dapat berupa dokumen-dokumen dasar.

Blok model : terdiri dari kombinasi prosedur, logika dan model matematik yang akan memanipulasi data input dan data yang tersimpan di basis data dengan cara yang sudah tertentu untuk menghasilkan keluaran yang diinginkan.

Blok keluaran : merupakan keluaran yang merupakan informasi yang berkualitas dan dokumentasi yang berguna.

Blok teknologi : digunakan untuk menerima input, menjalankan model, menyimpan dan mengakses data, menghasilkan dan mengirimkan keluaran dan membantu pengendalian dari sistem keseluruhan. Teknologi itu sendiri terdiri dari 2 bagian utama, yaitu perangkat software dan hardware.

Blok basis data : kumpulan dari data yang saling berhubungan satu dengan yang lainnya, tersimpan di perangkat keras komputer dan digunakan perangkat lunak untuk memanipulasinya.

Blok kendali : dirancang dan diterapkan untuk mencegah hal-hal yang dapat merusak sistem ataupun kesalahan-kesalahan yang dapat terjadi sewaktu sistem diimplementasikan. 


\section{METODOLOGI PENELITIAN}

Metodologi penelitian adalah gambaran langkah-langkah yang ditempuh dalam menjalankan penelitian, Metode yang digunakan untuk pengembangan sistem yang akan dibuat adalah metode waterfall. Metode waterfall adalah sebuah metode pengembangan sistem atau software yang bersifat sekuensial linier yaitu proses pengerjaan dari suatu system dilakukan secara berurutan dan sistematis. Berikut ini merupakan tahapan - tahapan dari metode waterfall:

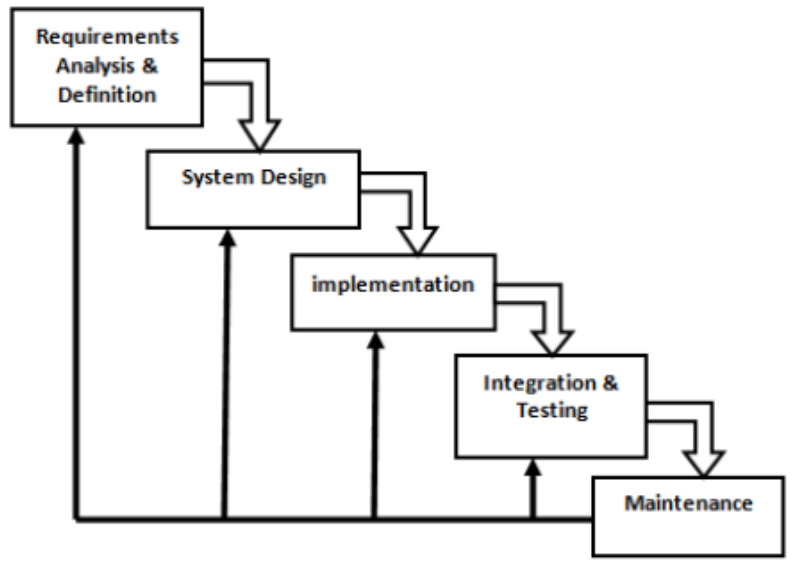

Gambar 1. Tahapan Dalam Model Waterfall

Secara garis besar metode waterfall mempunyai tahapan sebagai berikut ini :

\section{Analisa dan Definisi Kebutuhan (Requirement Analysis and Definition)}

Pada tahap ini dilakukan analisa terhadap kebutuhan sistem baik software dan hardware. Dalam tahap ini juga dilakukan proses pengumpulan data dengan cara melakukan studi literatur, wawancara, observasi dan dokumentasi mengenai data - data santri yang diperlukan. Tahapan ini akan menghasilkan dokumen user requirement atau data yang berhubungan dengan keinginan user dalam pembuatan sistem. Dokumen ini yang akan menjadi acuan dalam tahap desain sistem.

2. Desain Sistem (System Design)

Tahap desain sistem akan menerjemahkan syarat kebutuhan ke sebuah perancangan perangkat lunak sebelum dibuat coding. Pada proses ini dibuat perancangan arsitektur perangkat lunak, struktur data, representasi interface, dan algoritma prosedural.

3. Pembuatan Sistem (Implementation)

Pada tahap ini dilakukan penerjemahan dari proses desain kedalam bahasa yang bisa dikenali oleh komputer. Dalam proses ini dilakukan pembuatan program (coding) sesuai dengan sistem. Bahasa pemrograman yang digunakan dalam sistem ini adalah PHP, database yang digunakan untuk menyimpan data adalah MySQL.

4. Integrasi dan Pengujian Sistem (Integration and Testing)

Pada tahap ini dilakukan pengujian terhadap program yang telah dibuat dengan cara melakukan uji coba terhadap semua fungsi dan modul pada sistem.

\section{Pemeliharaan (Maintenance)}

Sistem yang telah dibuat dapat mengalami perubahan yang disebabkan kebutuhan perkembangan fungsional dari user atau disebabkan penyesuaian terhadap perkembangan lingkungan seperti hardware, software, peripheral, atau sistem operasi baru.

\section{HASIL DAN PEMBAHASAN}

Dalam memberikan keamanan hak akses dalam Sistem Informasi Manajemen Pondok Pesantren, terdapat hak akses sesuai dengan bagiannya masing-masing. 


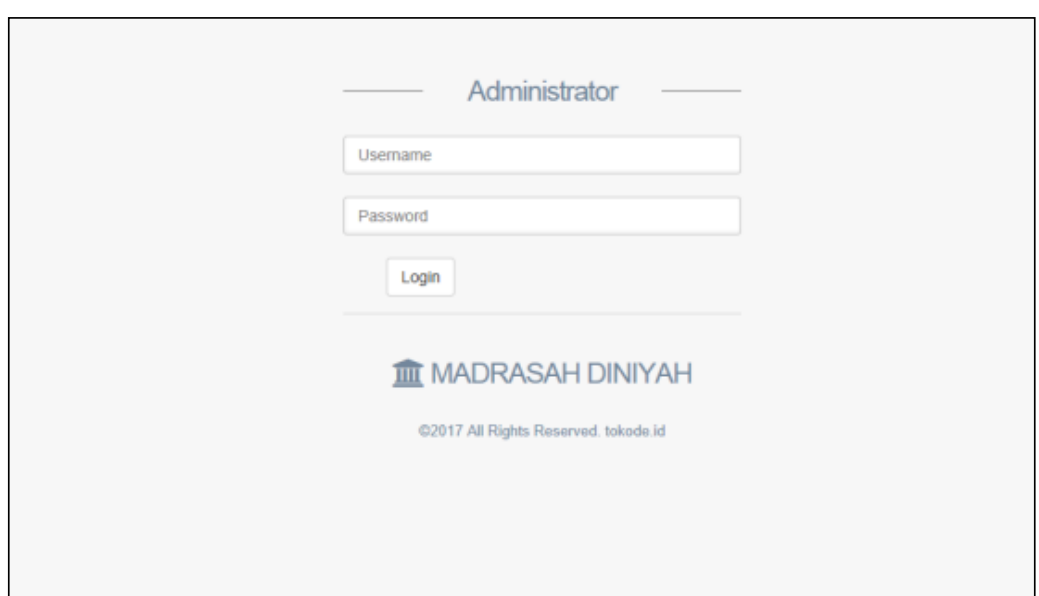

Gambar 2. Akses masuk sistem

Untuk memasukkan data santri Pondok Pesantren terdapat menu yang digunakan untuk memasukkan data santri sesuai dengan angkatan dan biodata lengkap untuk pengarsipan santri pondok pesantren.

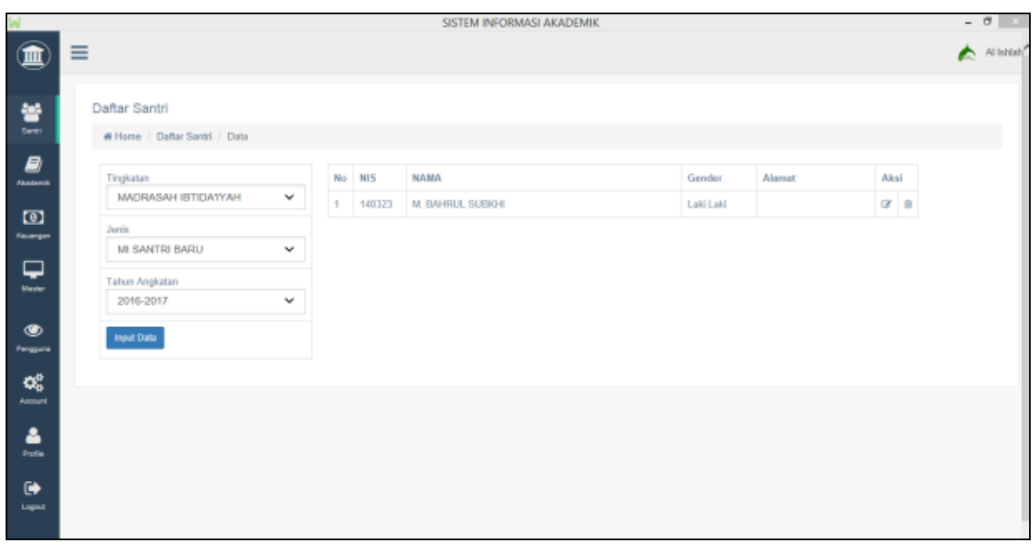

Gambar 3. Input data santri

Dalam pengelolaan Pondok Pesantren pasti ada dana untuk pengembangan Madrasah ataupun Pondok Pesantren, maka data keuangan perlu diberikan agar data keuangan Madrasah dan Pondok pesantren dapat dikelola dengan baik.

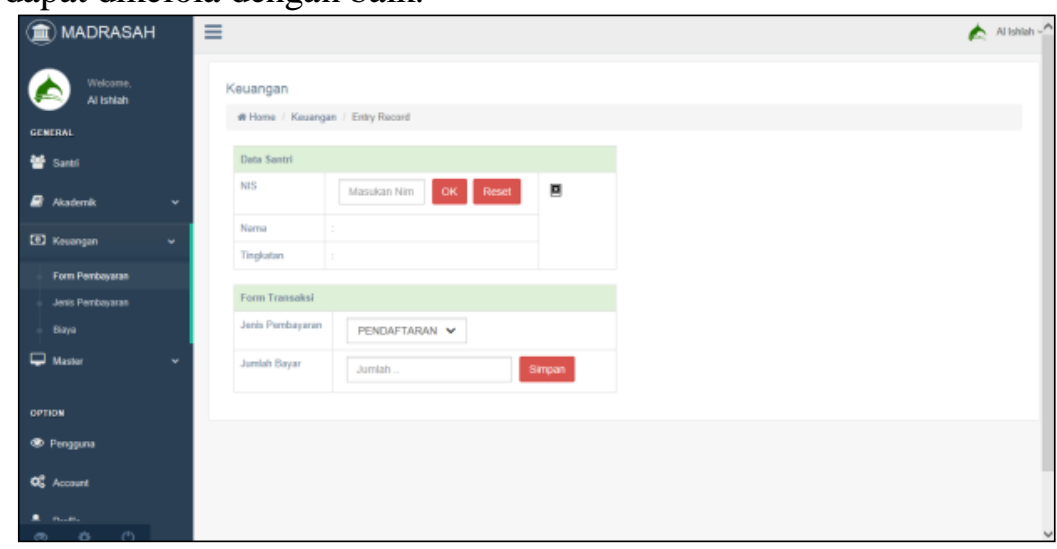

Gambar 4. Input data Keuangan

Dalam pembayaran Madrasah dan Pondok Pesantren perlu diberikan pendataan jelas tentang jenis pembayaran yang ada di Pondok Pesantren, maka sistem keuangan diberikan inputan khusus tentang jenis pembayaran. 


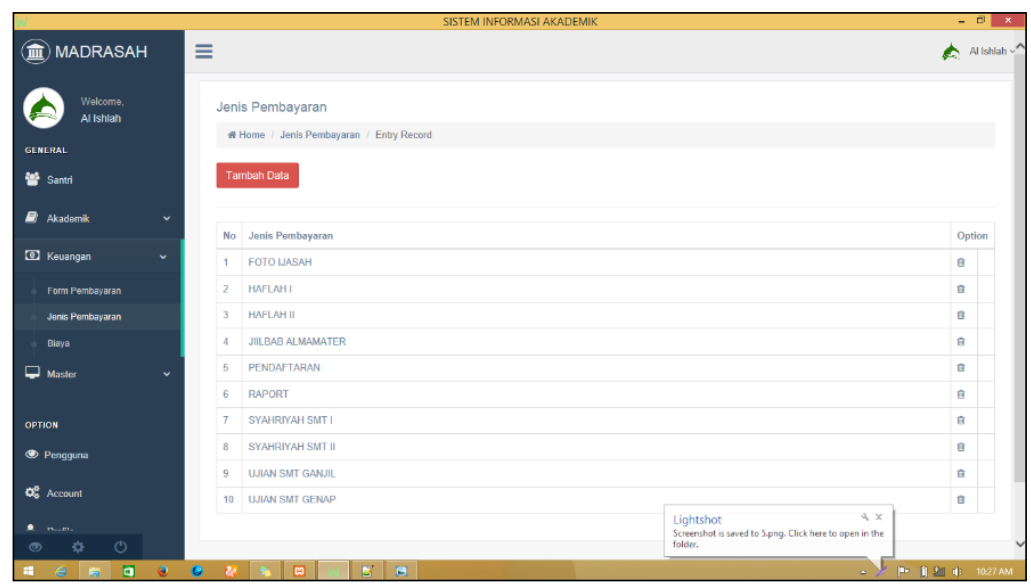

Gambar 5. Input Jenis pembayaran

Di Pondok pesantren terdapat kurikulum yang perlu untuk dimasukkan dalam sistem, untuk mempermudah pengurus dalam pengaturan kurikulum dan terkait santri madrasah.

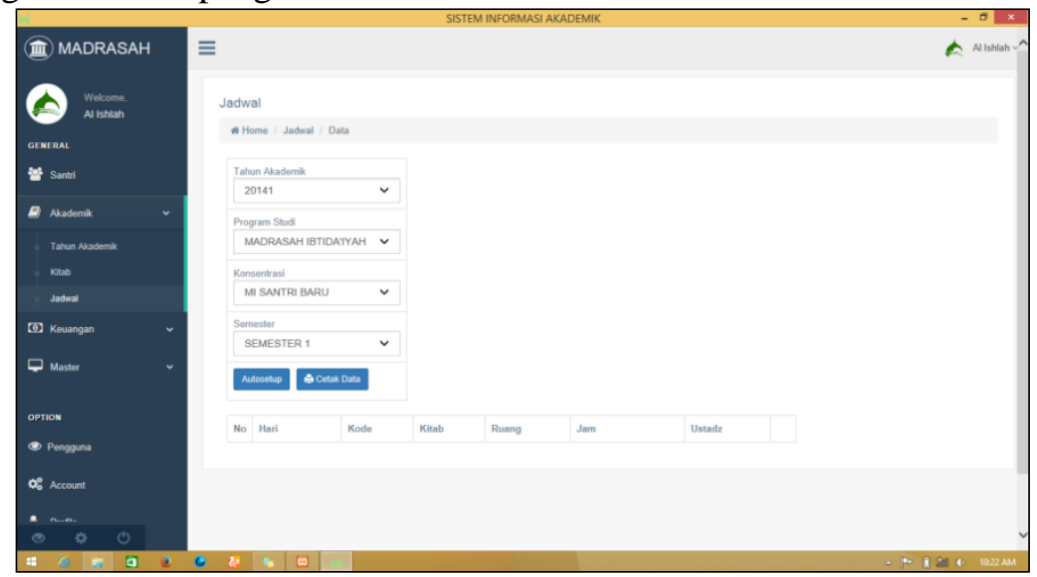

Gambar 6. Input Kurikulum Madrasah

\section{KESIMPULAN}

Dari hasil Implementasi Sistem Informasi Manajemen di Pondok Pesantren, didapat data santri yang mempunyai data yang bisa diketahui riwayat pembayaran dan riwayat madrasah, untuk menentukan kebijakan keuangan maka data pembayaran dibagi sesuai dengan kebutuhan setiap pondok.

\section{DAFTAR PUSTAKA}

[1] Jogiyanto, HM, Analisis dan Desain Sistem Informasi : Pendekatan Terstruktur Teori dan Praktek Aplikasi Bisnis, Yogyakarta : Andi, 2005

[2] Andri Kristanto, 2008. Perancangan Sistem Informasi. Gava Media.Yogyakarta

[3] Aji Supriyanto. 2005. "Pengantar Teknologi Informasi". Edisi Pertama. Penerbit Salemba Empat. Jakarta.

[4] McLeod, Jr., Raymond; Schell, George P. 2011. Sistem Informasi Managemen (Terjemahan). Jakarta: Salemba Empat

[5] Scott, George M. 2004. Prinsip-prinsip Sistem Informasi Manajemen (Terjemahan). Jakarta : PT Raja Grafindo Persada 
